\title{
Contribution of Female Entrepreneurs in Promoting Local Food to Support Tourism in Bali
}

\author{
Putu Sucita Yanthy, N. Darma Putra and I Komang Gde Bendesa
}

\author{
Doctorate Program in Tourism \\ Universitas Udayana \\ Corresponding author: putusucitayanthy@yahoo.com
}

\begin{abstract}
ARTICLE INFO
Received

20 February 2016

Accepted

30 August 2016

Available online

15 September 2016
\end{abstract}

ABSTRACT

This study analyzed the contributions of Balinese female entrepreneurs in

the culinary industry in promoting local food to support tourism in Bali. Research was undertaken in the area of Bali province and data were obtained from observations, interviews and study of literature supported by the theory of invented tradition. Eight Balinese warrior of culinaries were interviewed supported by food bloggers, literature reviews and documentation. Data were analyzed based on descriptive qualitative. The results show that Balinese female entrepreneurs have: (1) popularized Balinese food, (2) preserved the existence of Balinese food, (3) strengthened the Balinese culinary identity, and (4) supported tourism in Bali.

Keywords: balinese food, women's contributions

\section{Introduction}

\section{Background}

Researches on women in the tourism industry have been conducted by many scholars who dedicate their knowledge to study women in their various roles, both domestic and public. Cukier, Norris and Wall (1996) studied women involved in the tourism industry particularly those working as art shop staff; Sri (2013) had a research on women engaged in the tourism business as homestay operators; Janapriati (2015) studied women working as spa therapists, while Oka (2015) conducted a study on women working aboard cruise ships. Although there are a variety of roles owned by women who are actively engaged in public, the most frequently highlighted one is their role as an employee. However, some studies had started to raise the awareness regarding women's other roles in the public sphere, such as a study conducted by Ling, Juo and I.Jionghua (2011) which revealed that women have an important contribution in promoting tourism in Sarawak, while a study conducted in Bali by Putra (2014) put a highlight on four female characters referred to as 'culinary heroines' (In Indonesian: 'srikandi kuliner').

Women's contributions in the development of the tourism industry are very important, yet there are not many studies which discuss that, and there is still lack of appreciation for women's contributions in the tourism industry. One of the activities in the tourism industry which may be appropriate for women as they may have a potential for it, is the culinary activity. The people involved in this industry particularly in Bali are mostly women. They are the owners of the warung (food stalls) and restaurants who have been running their business for decades since Indonesia gained its independence through the time when the tourism in Bali started to develop and to date. It is very important to note their contributions considering that presently the culinary industry has a strong role to support the sustainability of tourism in 
Bali. As a supporting part of tourism, the culinary industry has gained many people's interest. Domestic and foreign tourists have begun to show an increased interest in Balinese food. They explore many places in Bali to find the typical dishes of Bali and tell the whole world about the unique taste and presentation.

Observers and those who are interested in the culinary world also have an important role in introducing Balinese culinary delights. Food Bloggers like 'Epicurina', 'Balikalapmakan', 'Food in Frame Bali', and 'Delicious Food Bali' are competing to gather accurate information on Balinese food and pack the information with interesting visuals which make Balinese food become increasingly popular as a tourist attraction. In addition to the food bloggers, now there are easy-to-find books on Balinese culinary recipes the authors of which describe Balinese foods in detail. Some of the authors are Ida Ayu Soraya with her book titled Masakan Bali (2005); Janet deNefee with her books titled Fragrant Rice (2006), Bali the Food of My Island Home (2010), and To Stir with Love (2010); Nanik Mirna Agung with Pawon Bali 60 Resep Masakan Khas Bali (2010); Krugger with Balinese Food (2014); Bondan Winarno with 100 Maknyus Bali (2015); and Ketut Gogonk with Resep Kuliner Warisan Leluhur (2015).

Balinese food is not easy to be introduced as food that can be enjoyed by people from various cultures because many people still consider that Balinese food contains pork. However, it cannot be denied that for years one of the well-known Balinese foods is babi guling (Balinese roasted suckling pig) that is popular among many domestic and foreign tourists. Babi guling is indeed very easy to find in Bali for it is not only a culinary icon in Bali, but it is also used as a kind of Balinese offerings. Getting to know Balinese food also means getting to know part of Balinese cultures and traditions as most of the Balinese foods known today are types of offerings that are prepared by the Balinese for special events and days. Bondan Winarno at the launch of his book titled 100 Maknyus Bali on February 4, 2016 also indicated likewise. He argued that Balinese food is likely to be misunderstood. Many people do not clearly understand Balinese food. In fact, not only is Balinese

http://ojs.unud.ac.id/index.php/eot food delicious, but it also contains ingredients which have usefulness for the health of our body organs.

The recipes and processing methods are passed down by the ancestors to cooks in Bali called be lawa (Winarno, Tanod and Nazarudin, 2015:334). Be lawa are mostly men, because ngebat or paebat (a meat processing activity) in Balinese culture is mostly done by men. Be lawa itself is Bima's name when he disguised himself as an expert butcher. This skill is passed down to men. On the other hand, women are not directly involved in the paebat process as they normally prepare the food ingredients such as spices, rice, and its servings especially for offerings.

In the process of paebat or mebat, the main role is not played by women. Women usually take most part in daily cooking activities. Generally, Balinese women can cook either for their family or to fulfill the economic needs of their family. Many food stalls are run by women. Even many foreign chefs who come to Bali may choose to learn from women who are experts in making Balinese foods. Basically, women also excel at food processing and presentation. They can cook for their family and they can even sell home-made foods to people in their neighborhood through warung (food stalls). There are eight women selected as the subjects of this research and they are entrepreneurs in the culinary industry in Bali in the area of Kuta, Sanur and Ubud. They have a great contribution as the culinary businesses that they are running have become legendary icons in Balinese culinary business. They are Made Masih, Anak Agung Oka Sinar, Janet deNefee, Kadek Nilawati, Ni Wayan Murni, Sang Ayu Putu Wija, Made Weti, and Ni Ketut Tjuki.

These eight research subjects have their own ways in presenting their culinary delights. The selection of the research subjects were based on several criteria which include ownership of culinary business, the period of the operation of the culinary business, consistency and commitment in serving Balinese food menu at their food stalls or restaurants. The results of the interviews with Balinese food bloggers serve as the main source of information because those food 
bloggers have observed and written information on the food stalls and restaurants owned by the research subjects, and recommended the food stalls and restaurants owned by these female entrepreneurs as the best culinary destinations in Bali.

The research of Cukier, Norris and Wall (1996), entitled "The involvement of women in the tourism industry of Bali, Indonesia" is the first study on women's involvement in tourism industry particurarly in Bali the research shows the gap position between women and men in getting opportunities to get involved in the tourism industry. Putra (2014) state that women has a great opportunity to working intourism industry. Women in Bali also play an important role in the development of tourism not only as workers but as a pioneer and a successful tourism entrepreneur particularly in culinary sector. According to Konkol (2013) women in the culinary world, especially in the restaurant does have its own way and style in dealing with all kinds of challenges. Based on the literature review, these studies show that the contribution of women in the tourism industry is important to be analized especially in culinary sector. Women will be able to optimally their ability and creativity to support sustainable tourism industry through its contribution to the culinary business.

Many have argued that the tradition is something that has existed since the first and passed on across generations without any significant changes. Tradition is identified with everything that is ancient, old, and contrast with the modern. Hobsbawm and Ranger (1983) provides a new view of tradition. They said that what is often regarded as something that "Appear or claim to be old are Often quite recent in origin and sometimes invented", the intention is that something that looked or claimed as something old-fashioned, in fact it is often a new thing or it is often be something which has recently been discovered. Furthermore, Hobsbawm and Ranger stated the invented of tradition is taken to mean a set practices, normally governed by overtly or tacitly accepted rules and of a ritual or symbolic nature, which seek to inculcate certain values and norms of behaviour by repetition, which automatically implies continuity with the past. In fact, where possible, they normally attempt to establish continuity with a suitable historic past (Hobsbawm and Ranger, 1983:1).

\section{Research Objectives}

The purpose of this research is to study the rise of women in the culinary industry. Women have proven that they are successful in turning cooking that is part of their domestic chores into a business. They contribute in promoting and preserving the local food through warungs and restaurants which they have initiated since the development of tourism in Bali.

\section{Methodology}

The approach of this research is by examining the women enterpreneur in culinary industry who are involving also in tourism in Bali. Most of them established on 1960 and can be categorize as warung which provide the signature food of Bali in the other hand they also have several popular menu such as organic and fushion food that attract the tourist who need to experiences local food. This research was conducted in Kuta, Sanur and Ubud in 2015.

The research is a descriptive qualitative in which the researchers tried to explore the eight warrior of culinary actions by depth interviews with food bloggers, literature reviews and documentation. The first step is conducting obeservation of eight women enterpreneur in Bali and interviewing them trough in-depth interview. The second step is conducting interview with four popular food blogger (deliciousfoodbali, balikalapmakan, foodinframe, and epicurina). They comments are needed to reveals the women contributions in tourism industry. The data collected from the interviews were analyze using the descriptive- interpretative method and extracted to have more focus on answering the research problems and to achieve the aims of study.

\section{Results and Discussion}

Contributions of female culinary entrepreneurs are in any form of involvement, efforts and activities done by them as Balinese 
women to support tourism through their culinary business. These female culinary entrepreneurs are even considered as culinary pioneers in Bali by Putra (2014) who called them with the name 'srikandi kuliner' which means 'culinary heroines', while Winarno, Tanod and Nazarudin (2015) called them 'srikandi kuliner pusaka Bali' which means 'Balinese heritage food culinary heroines' because these women introduce Balinese food with the very own characteristic of their Balinese cuisine through their own warung (food stalls) and restaurants.

In Kuta area, the research subjects are among others Made Masih, the owner of Warung Made (or Made's Warung) who started her business in 1969 and now has four branches, namely in Seminyak (since 1996), Benoa (since 2015), Amsterdam (since 2015), and I Gusti Ngurah Rai Airport (since 2016). Warung Made is a witness of the development of tourism in Kuta. In Ubud area, five famous female culinary entrepreneurs who are also the subjects in this research are among others, first, Anak Agung Raka Sinar, the owner of Babi Guling Oka (a food stall which sells Balinese roasted suckling pig) starting from the 1970s. She has been successful in promoting babi guling (Balinese roasted suckling pig) as a favorite food menu for tourists. Second, Sang Ayu Putu Wija, the owner of Warung Nasi Ayam Kedewatan (a food stall which sells Balinese chicken rice), who started her business since 1965 and her warung is very popular among domestic tourists. The third one is Ni Wayan Murni, a pioneer of Ubud tourism and the owner of Murni's Warung, well known for her culinary business of international standards in 1974. The fourth female entrepreneur as a subject in this research is Janet deNefee or Nyoman Jepun, who started her culinary business in 1987 and is the owner of the restaurants named Casa Luna and Indus. She is also known as the organizer of Ubud Food Festival. The fifth one is Kadek Nilawati, the owner of Warung Bodag Maliah. She has been a pioneer of organic food in Ubud since 2000. Meanwhile, in Sanur area, the research subjects are two famous warung owners in Sanur beach. They are Ketut Tjuki, the owner of Warung Mak Beng that is consistent with its fish menu and has been known for its typical sambal since 1941; and Made Weti, the owner of Warung Nasi Campur Bali Men Weti (selling Balinese mixed rice) since 1976 whose food was awarded as Street Master Food of the year in 2013.

Based on the observations and information collected through interviews and papers about these eight female culinary entrepreneurs, there are four important points to be considered as the contributions of female culinary entrepreneurs in promoting Balinese food. They are (1) popularizing Balinese food, (2) maintaining the existence of Balinese food, (3) strengthening the Balinese culinary identity, and (4) supporting tourism in Bali.

\section{(1) Popularizing Balinese Food}

Culinary delights served in the food stalls and restaurants owned by the research subjects in the area of Ubud, Sanur and Kuta can be categorized as or 'Hits food' (very popular food) and 'signature food'. Very popular food is a category of food that is unique and popular, which attracts the interest of tourists to try. The development of very popular food can be seen in the area of Kuta and Sanur through the emergence of warung (food stalls) and restaurants with interesting themes presenting unique food of many parts of the world which through a process of transformation can be enjoyed by domestic and foreign tourists. Signature food is food classified as a culinary legend that has its popularity as an icon of a region. The food categorized as signature food is a legacy or heritage the taste and presentation of which does not undergo changes.

The female culinary entrepreneurs are people who have popularized Balinese food through the food that they sell which can be classified as very popular and signature food. There is a tendency that food stalls and restaurants selling food that are categorized as signature food have minimum changes in the presentation of their dishes. Made's Warung, Warung Babi Guling Oka, Ayam Kedewatan, Murni's Warung, Warung Men Weti and Mak Beng are warung (food stalls) that sell food categorized as signature food of each region while Warung Sari Organik Bodag Maliah, and Casa Luna/Indus sell food categorized as very popular food.

e-ISSN: 2407-392X. p-ISSN: 2541-0857 
(2) Maintaining the Existence of

\section{Balinese Food}

Consistency in the presentation of food in their warung (food stalls) and restaurants for decades, is part of these female entrepreneurs' efforts and contributions to maintain the existence of Balinese food. The business of warung (food stalls) that they manage provide contributions by maintaining the existence of local food. Unfortunately there are inadequate records and documentation on Balinese food. Hence, it is not surprising that some Balinese food is unknown or even never served. It is great that these female culinary entrepreneurs have strived to maintain the existence of Balinese food through their warung. Although they have been running their business for decades, they still uphold the idea that maintaining the originality of their Balinese food taste is important.

These women have a huge contribution to the development of the culinary industry in Bali. The key of the success that they have achieved lies in their very own character. The character of a strong Balinese woman is reflected in these female entrepreneurs. These female entrepreneurs are very consistent in maintaining their culinary delights and being strict in maintaining the originality, and they have love and sincerity in maintaining the existence of Balinese food as the Balinese culinary identity.

\section{(3) Strengthening Balinese Culinary Identity}

Like cultures, food is also part of the identity of a region. Balinese food such as lawar (Balinese a dish created from a mixture of vegetables, coconut and minced meat mixed with rich herbs and spices), sate lilit (Balinese minced satay), babi guling (Balinese roasted suckling pig), betutu (Balinese chicken dish), and sambal (Balinese mixture of spices) are unique Balinese culinary delights that can be found in every regency in Bali. Each of these foods has similarities and differences. Let's take an example sambal. Most Balinese people never forget to include sambal to complement their food because Balinese people are known to love spicy food. In Bali alone there are 457 types of sambal. A type of sambal typical of Bali is sambal matah (Balinese raw shallot and

http://ojs.unud.ac.id/index.php/eot lemongrass relish). Regardless whatever the dish is, Balinese food stalls or restaurants normally serve sambal matah. Likewise, betutu is also a type of very popular Balinese cuisine. If we have a look at the menus in their warung and restaurants, we will see that these female entrepreneurs also serve betutu. According to Caplan (2003), food can be understood as part of a system of cultures since cultures and social control play a role in the creation of the food taste. Food is very complex because it can be associated with the customs, history, and traditions of a region.

The variety of Balinese food was in fact introduced by kings of Bali and the people living around the palaces. Actually, all food consumed by the kings have favorable effects such as for anti-aging, virility, good for the skin and most importantly for health. In the Balinese belief, there are five kinds of spices based on the five directions where gods worshiped in Bali reside. Balinese spices are divided into two, namely base gede (the most complete sambal) and basa madya (the less complete one), but both have the same ingredients sourced from bebungkilan (spices) consisting of alpinia galanga, ginger, turmeric, kaempferia galangal $\mathrm{L}$ and cassumunar ginger. The belief has become a habit for the Balinese to use these spices and basa genep (complete spices) in each Balinese food. Long time ago, in the era of kingdoms in Bali, only kings could enjoy foods with base genep. This tradition was later passed on to the public so the people could enjoy what the kings enjoyed. Now this tradition can be easily enjoyed by tourists by simply ordering food the form of presentation of which is adapted from the food presentation style for kings of Bali.

Hobsbawn and Ranger (1983) mention that a tradition can undergo a transformation by appearing as a new function as a form of adaptation through changes and innovations. The tradition of preparing food by using bumbu genep (complete spices) is part of Balinese culture that is done in paebatan. Hence, female entrepreneurs who use basa genep have used part of the identity of Balinese food. The use of basa genep is one of the efforts to preserve the culinary identity of Bali. Despite diverse types of basa genep, it remains an element that strengthens the Balinese food identity. 
The female culinary entrepreneurs also contribute in shaping the Balinese food identity. The taste and presentation of the food in the stalls and restaurants that they manage is a culinary identity of Bali. For example the food served by Warung Men Weti dan Mak Beng reminds the visitors of the area of Sanur. Babi Guling Bu Oka, and Nasi Ayam Bu Mangku are iconic Balinese culinary delights in Ubud. Each food characterizes each tourism area in Bali and the food certainly contains base genep. Balinese culinary identity can be seen from the presentation of nasi campur (mixed rice) which is one of the top dishes in these female entrepreneurs' warung. Almost all of the warung and restaurants provide mixed rice. Nasi campur Bali (Balinese mixed rice) is a universal dish in Bali with some variations. Some nasi campur may use pork, chicken, duck meat, sate lilit (minced satay), and urap (mixed vegetable). Figure 1 below contains pictures of mixed rice. From the left to the right are nasi campur of Warung Made, Warung Nasi Ayam Kedewatan, Warung Men Weti and Warung Bodag Maliah. Nasi campur that they serve has reflected Balinese food with Balinese spices in each food.
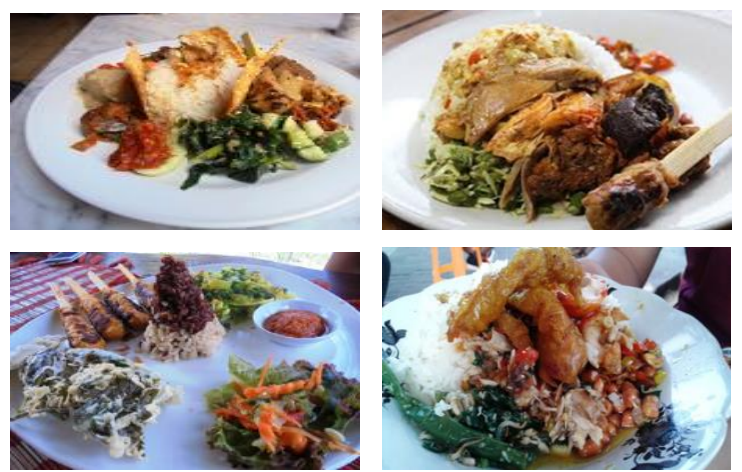

Figure 1. Mixed Rice

Source: Research Photos

\section{(4) Supporting Tourism in Bali}

The contributions of these women to support the tourism in Bali through their culinary business are indicated by their consistency in running their culinary business that they founded. Their culinary business activities have an impact on tourism in Bali. Their culinary businesses that have been running over decades have promoted local food (Balinese food) to be more known by tourists. These food stalls and restaurants provide exciting and fascinating culinary experience for tourists, and introduce types of

http://ojs.unud.ac.id/index.php/eot
Balinese foods. Culinary businesses have become more appealing to be developed in Bali by promoting various types of Balinese culinary delights with a touch of creativity to further support the development of tourism in Bali. Tourists will find it very easy to find food stalls and restaurants serving Balinese food.

Warung Made Masih in Kuta is a witness of the development of tourism in the region which would certainly motivate the local people around this warung to also see the opportunities to open a culinary business. Meanwhile, Murni's Warung in Ubud as a tourism pioneer will of course increase local interest to be involved in the field of culinary. These female entrepreneurs also become an example or role model for other culinary entrepreneurs, and consequently, many culinary experts and chefs have confidence to invest in culinary businesses. They are among others Bondan Winarno, William Wongso and Will Meyrick.

As female entrepreneurs, their contributions in supporting the tourism in Bali are among others by establishing Balinese food branding. Babi guling, nasi campur (mixed rice), sup ikan (fish soup), and betutu are dishes that have been served since the opening of the stalls and restaurants. They have also created a local branding for Balinese food which also indirectly promotes Balinese food to domestic and foreign tourists. Without $\mathrm{Bu}$ Oka, Balinese roasted suckling pig ( $b a b i$ guling) will not be as well-known as it is now. The same would happen to nasi campur as one of the foods served by these female entrepreneurs to promote Balinese food to become very popular and attractive to tourists. The same case applies for fish soup which is a typical dish of Sanur Beach.

Culinary activities such as enjoying the local food and participating in the activities of food processing are activities that can directly introduce the traditions and culture of Bali. This activity is a part of the strategies taken by warung and restaurants like Warung Babi Guling Oka to introduce Balinese traditions and cultures which allow tourists to participate in the activities ranging from slaughtering pigs to process it to become a roasted suckling pig and a variety of other foods, to showing the

e-ISSN: 2407-392X. p-ISSN: 2541-0857 
tourists that they still use firewood to cook and also introducing Balinese spices in every Balinese cuisine. Warung Bodag Maliah allows tourists to come to their garden and pick their own vegetables to be processed into food, while Janet opens a cooking class that incorporates a menu of Balinese cuisine. The contributions of the female entrepreneurs are apparent based on the description above and evidenced by the business that they operate which have an impact on the development of tourism in Bali. Culture is not always introduced through dances and artistic traditions of Bali which have frequently presented to tourists. Food also takes part in the promotion of tourism in Bali through culinary businesses and activities therein.

\section{Conclusion}

The female culinary entrepreneurs undoubtedly have a huge contribution in promoting Balinese food. These women popularize Balinese food, maintain the existence of Balinese food, strengthen the Balinese food identity and support the tourism in Bali with their creativity in presenting and transforming the food to be their top culinary delights in the warung and restaurants that they manage. The Balinese culinary delights that they have popularized, attract tourists who have interest in culinary to come to try and enjoy it. These female entrepreneurs have contributed both in the context of maintaining the existence of the Balinese food and supporting the tourism development. Consistency and commitment in serving Balinese cuisine have supported the development of Balinese food as the potential to promote tourism. This is a form of an effort to maintain the existence of Balinese food by continuously serving and maintaining the originality of the Balinese food taste. Typical Balinese culinary taste served in these entrepreneurs' warung and restaurants have strengthened the identity of Balinese food in the eyes of various culinary tourists and they are accepted as part of the characteristics of Bali as a tourist destination.

\section{Acknowledgement}

I would like to extend my deepest gratitude to the eight female culinary entrepreneurs as the subjects of this research

http://ojs.unud.ac.id/index.php/eot and the food bloggers as informants in this study who were willing to provide information and permission in collecting the data needed to support this article.

\section{References}

Caplan, P. (2003) Food Health and Identity. New York: Routledge.

Cukier, J., Norris, J. and Wall, G. (1996) 'The involvement of women in the tourism industry of Bali, Indonesia', The Journal of Development Studies. Taylor \& Francis, 33(2), pp. 248-270.

Hobsbawm, E. and Ranger, T. (1983) The Invention of Tradition. United Kingdom: The Cambridge University.

Janapriati, D. A. L. (2015) Analisis Kinerja Pelayanan Spa di Kabupaten Badung dan Gianyar. Udayana University.

Konkol, S. M. (2013) Someone's in The Kitchen, Where's Dinah? Gendered Dimensions of the professional Culinary World. DePaul University.

Ling, R., Juo, S. and I.Jionghua, L. (2011) Contribution of Women in Long House Tourism. China: Peking University Linnaus University.

Oka, I. M. D. (2015) Perempuan Bali dalam Industri Pariwisata Kapal Pesiar. Udayana University.

Putra, I. N. D. (2014) 'Empat Srikandi Kuliner Bali: Peran Perempuan Dalam Pembangunan Pariwisata berkelanjutan', JUMPA, 1(1), pp. 6594.

Sri, A. A. P. (2013) 'Faktor-faktor yang memotivasi perempuan sebagai pengelola pondok wisata di kelurahan Ubud kecmatan Ubud, Kabupaten Gianyar', AnalisisPariwisata, 13(1).

Winarno, B., Tanod, L. and Nazarudin, H. (2015) 00 Maknyus Bali. Jakarta: Jalansutra. 